\title{
Bireylerin Koronavirüs Anksiyete Düzeylerinin Psikolojik Sağlamlıklarına Etkisi
}

\author{
The Effect of Individuals' Coronavirus Anxiety Levels on Their Psychological Resilience
}

\author{
Necla İrem ÖLMEZOĞLU İRI ${ }^{1}$, Fatma KORKMAZ ${ }^{2}$
}

\begin{abstract}
ÖZ
Bu çalışmanın amacı; COVID-19 salgını sürecinde Türkiye'de yaşayan bireylerin sosyo demografik özellikleri ile koronavirüs anksiyete düzeyleri ve psikolojik sağlamlıkları arasındaki ilişkinin incelenmesidir. Kesitsel ve tanımlayıcı tipte olan çalışmanın evrenini, araştırmaya katılmayı kabul eden 15 yaş üstü bireyler oluşturmaktadır. Araştırma kapsamında 425 bireye ulaşılmıştır. Araştırmanın verileri çevrimiçi anket yöntemi (Google Forms aracılığıyla) ile toplanmıştır. Veri toplama aracı olarak; araştırmacıların hazırladığı "Kişisel Bilgi Formu” ile Lee (2020)'nin geliştirdiği ve Biçer ve diğerlerinin (2020) Türkçe 'ye çevirdiği "Koronavirüs Anksiyete Ölçeği (KAÖ)" ve Smith ve diğerlerinin (2008) geliştirdiği ve Doğan (2015)'nın Türkçe 'ye çevirdiği "Kısa Psikolojik Sağlamlık Ölçeği (KPSÖ)" kullanılmıştır. Verileri analiz etmek için ise SPSS 22 ve AMOS 24 istatistik paket programlarından yararlanılmıştır. Araştırma sonuçlarına göre, öğrenciler, ev hanımları, kamu sektörü çalışanları, özel sektör çalışanları, serbest çalışanlar, emekliler ve işsizlerden oluşan gruplar içerisinde emeklilerin ve ev hanımlarının koronavirüs anksiyete düzeyleri anlamlı derecede daha yüksek bulunmuştur. Ayrıca kadınların erkeklere göre koronavirüs anksiyete düzeylerinin daha yüksek olduğu görülmüş ve kadınların psikolojik sağlamlık düzeylerinin daha düşük olduğu tespit edilmiştir. Öte yandan; katılımcıların eğitim durumu ve aylık gelirinin koronavirüs anksiyete ve psikolojik sağlamlık düzeylerini etkilemediği bulunmuştur. Son olarak, bu çalışma koronavirüs anksiyetesinin psikolojik sağlamlık üzerinde istatistiksel açıdan anlamlı ve negatif yönde orta düzeyde etkisi olduğunu ve psikolojik sağlamlıkta meydana gelebilecek bir azalmanın \%20'sinin koronavirüs anksiyetesi ile açıklanabileceğini ortaya koymaktadır.
\end{abstract}

Anahtar Kelimeler: Koronavirüs, Anksiyete, Psikolojik sağlamlık.

\begin{abstract}
The aim of this study is to examine the relationship between socio-demographic characteristics of individuals living in Turkey during the COVID-19 outbreak and coronavirus anxiety levels and psychological resilience. The population of the study, which is a cross-sectional and descriptive type, consists of individuals over the age of 15 who agree to participate in the study. 425 individuals were reached within the scope of the research. Data from the study was collected using the online survey method (via Google Forms). "Personal Information Form" developed by researchers, "Coronavirus Anxiety Scale (CAS)" developed by Lee (2020) and translated into Turkish by Biçer et al. (2020), and "Brief Psychological Resilience Scale (BRS) " developed by Smith et al. (2008) and translated into Turkish by Doğan (2015) were used as data collection tools. SPSS 22 and AMOS 24 package programs were used together in the analysis of the data. According to the results of the research, when examining students, housewives, public sector employees, private sector employees, freelancers, retirees and the unemployed group, the coronavirus anxiety levels of retirees and housewives were found to be significantly higher. In addition, women were found to have higher levels of coronavirus anxiety than men, and women were found to have lower levels of psychological resilience. On the other hand, it was found that the educational status and monthly income of the participants do not affect their Coronavirus anxiety and psychological resilience levels. In conclusion, this study reveals that coronavirus anxiety has a statistically significant and negatively moderate effect on psychological resilience and $20 \%$ of a decrease in psychological resilience can be explained by coronavirus anxiety.
\end{abstract}

Key Words: Coronavirus, Anxiety, Psychological resilience.

Araştırma için Gümüşhane Üniversitesi Bilimsel Araştırma ve Yayın Etiği Kurulu’nun 24/09/2020 tarih ve 2020/9 karar sayısı ile izin alınmıştır. Ayrıca bu araştırma için Sağlık Bakanlığı'ndan 20/12/2020 tarihinde gerekli araştırma izni alınmıştır.

${ }^{1}$ Dr. Öğr. Üyesi, , Gümüşhane Üniversitesi, Mülkiyet Koruma ve Güvenlik Bölümü, neclaolmezoglu@gumushane.edu.tr, ORCID: 00000003-2997-3343

${ }^{2}$ Dr. Öğr. Üyesi, Kamu Yönetimi, Yozgat Bozok Üniversitesi, Siyaset Bilimi ve Kamu Yönetimi, ftmttk1 @ gmail.com, ORCID: 0000-00030164-1136 


\section{GíRiș}

Çin'in Wuhan kentinde 2019 Aralık ayında ortaya çıkan ve Dünya Sağlık Örgütü (DSÖ) tarafindan yeni bir koronavirüs (COVID-19) olarak duyurulan salgin hastalık kısa sürede ve beklenmedik şekilde tüm dünyayı etkisi altına almıştır. ${ }^{1}$ Tüm dünyada virüs vakalarındaki ve ölüm sayılarındaki artışla birlikte alınan kısıtlama önlemleri, karantina uygulamaları, seyahat engelleri ile eğitime ara verilmesi gibi önlemler insanların çalışma yaşamından alışveriş, sosyalleşme ve geleceği planlama şekillerine kadar günlük yaşantılarında önemli değişimlere neden olmuştur. ${ }^{2-3}$ Diğer taraftan yaşanan bu ani değişim insanların psikolojik olarak sorun yaşamasına ve ruhsal olarak etkilenmesine neden olmuştur. ${ }^{4-5}$ Yakın tarihte Çin'de ögrenciler ve genel nüfus arasında yapılan araştırmalarda, katılımcıların yaklaşık \% 2535'inin COVID-19 salgını sirasında anksiyete (kayg1) semptomlarından veya psikolojik stresten muzdarip olduğu ortaya konmuştur. ${ }^{6-}$ 7-8-9 Benzer şekilde Li ve diğerlerinin $(2020)^{10}$ yürüttüğü çalışmada da COVID-19 salgınının, insanların olumlu duygularını

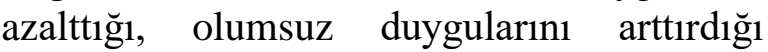
sonucuna ulaşılmıştır. Stresli bir süreç olarak ifade edilen salgın dönemlerinde insanlarda yaşanan endişe ve panik hali belirli bir süre sonra şiddetli anksiyeteye dönüşebilmektedir. Geçmiş salgınlar ve salgınlarla ilgili önceki çalışmalar (örn., Ebola 2014/2016, H1N1 2009/2010, kuş gribi 2006, SARS 2003) bu dönemlerde endişe veya anksiyetenin yaygın olduğunu göstermiştir. ${ }^{11-13}$

Günümüzde COVID-19 salgınıyla mücadele edilmesi salgın ve ruh sağlığı konusunu yeniden gündeme taşımıştır. ${ }^{14} \mathrm{Bu}$ açıdan bireylerde anksiyete düzeyinin saptanması ve bu sürecin nasıl yönetilebileceğine ilişsin bilgi sahibi olunması oldukça önemlidir. ${ }^{15}$

Anksiyete diğer adıyla kaygı, insan olmanın en temel evrensel duyguları arasında yer alan bir değer olarak kabul edilmektedir. Anksiyete köken olarak Yunanca'da merak, endişe ve korku anlamına gelen "anxietas" teriminden türetilmiştir. ${ }^{16}$ Spielberger anksiyeteyi, sinir sisteminin uyarılmasıyla ilişkili öznel bir gerginlik, sinirlilik ve endişe hissi şeklinde tanımlamaktadır. ${ }^{17}$ Anksiyeteyi çok çeşitli duygusal ve davranış bozukluklarından biri olarak belirten Rachel ve Chidsey bir kişinin yüksek düzeyde anksiyete yaşamasını, onun yaşamını zora sokan ve yaşamını engelleyen bir durum olarak tanımlamaktadır. ${ }^{18}$ Koronavirüs anksiyetesi ise, belirli bir sağlık kaygısı biçimi veya ciddi bir tıbbi duruma yakalanma konusunda takıntılı ve mantıksız endişe olarak kavramsallaştırılabilir.

Diğer taraftan DSÖ Avrupa direktörü Kluge'a göre, koronavirüs anksiyetesi başta olmak üzere salgının psikolojik etkilerinin azaltılmasında bireylerin psikolojik sağlamlık düzeyi kritik öneme sahiptir. ${ }^{19}$ Ruh sağlığ açısından oldukça önemli bir kavram olan psikolojik sağlamlık, genel olarak aşırı stres veya travmaya veya olumsuz deneyime başarılı bir şekilde yanıt verme yeteneği olarak tanımlanmaktadır. Sikıntıdan kolayca kurtulma ve olumsuz koşullarda olumlu duygular kullanabilme yeteneği olarak da tanımlanan psikolojik sağlamlık COVID-19 salgınının olumsuz etkilerinin azaltılmasında kilit rol üstlenmektedir. ${ }^{20}$

Psikolojik sağlamlık (resilience) kavramı, Latince 'de esnek, elastik olma anlamına gelen "resilire" fiilinden türetilmiştir. ${ }^{21}$ Kavram, temelde matematik ve fizik bilimlerinde, bir malzemenin değişikliğe uğradıktan sonra yeniden eski dengesine dönmesini tanımlamak üzere kullanılmaktadır. ${ }^{22}$ Buna ek olarak kavramın, pozitif psikoloji alanında ruh sağlığı ile ilgili çalışmalarda da kullanıldığı görülmektedir. İnsanların olumlu özelliklerinin geliştirilmesine ve nihayetinde psikolojik sağlıklarının korunmasına odaklanan pozitif psikoloji biliminde kavram, olumsuz duygusal deneyimlerden geri dönme ve stresli deneyimlerin değişen taleplerine esnek bir şekilde uyum sağlama becerisi şeklinde tanımlanmaktadır. ${ }^{23}$ Psikolojik sağlamlık konusunda literatürde üzerinde uzlaşılan bir tanım bulunmamasına rağmen yapılan tanımlamalarda iki kritik nokta üzerinde uzlaşıya varıldığg görülmektedir. Bu kritik 
noktalardan ilki önemli bir tehdit ya da olumsuz bir duruma (riske) maruz kalmak ikincisi karşılaşılan olumsuz durum karşısında uyum gösterebilmektir. ${ }^{24}$

Yapılan araştırmalar psikolojik sağlamlık düzeyleri iyi olan bireylerde anksiyete belirtilerinin daha az görüldüğünü göstermiştir. ${ }^{25}$ COVID-19 salgınının olumsuz psikolojik sonuçlarını yönetmek için korku, kaygı ve stres gibi ilişkili psikolojik sonuçları araştırmak gerekmektedir. $\mathrm{Bu}$ nedenle bu çalışmada COVID-19 salgını nedeniyle bireylerde oluşan koronavirüs anksiyetesi ve psikolojik sağlamlık arasındaki ilişkinin tespit edilmesi amaçlanmıştır. $\mathrm{Bu}$ amaç doğrultusunda kesitsel ve tanımlayıcı tipte bir araştırma gerçekleştirilmiştir. Çalışmada literatürden farklı olarak yapısal eşitlik modeli kullanılarak koronavirüs anksiyetesinin psikolojik sağlamlık üzerinde etkisi açıklanmaya çalışılmıştır. Bu açıdan araştırma sonuçlarının literatüre önemli bir katkı sunması beklenmektedir.

\section{MATERYAL VE METOT}

Materyal ve metot kisminda, evren ve örneklem, analiz yöntemi, kullanılan ölçekler ve ölçeklerin geçerlik ve güvenirlik sonuçları ile araştırmaya ait etik izinlere ilişkin bilgiler yer almaktadır.

\section{Evren ve Örneklem}

Araştırma evrenini araştırmaya katılmayı kabul eden 15 yaş üstü bireyler, örneklemini ise bu evren kapsamında Google forms uygulaması kullanılarak çevrimiçi anket yöntemiyle ulaşılan 425 birey oluşturmaktadır. Örnekleme ilişkin demografik dağılımlar Tablo 1'de yer almaktadır.

Tablo 1. Örnekleme İlişkin Demografik Dağımlar

\begin{tabular}{|c|c|c|c|c|c|}
\hline Değişkenler & Frekans (425) & $\%(100,0)$ & Değişkenler & Frekans (425) & $\%(100,0)$ \\
\hline Cinsiyet & & & \multicolumn{3}{|l|}{ Yapılan İș } \\
\hline Kadın & 239 & 56,2 & Öğrenci & 139 & 32,7 \\
\hline Erkek & 186 & 43,8 & Ev Hanımı & 37 & 8,7 \\
\hline \multicolumn{3}{|l|}{ Medeni Durum } & Kamu Çalışanı & 96 & 22,6 \\
\hline Evli & 185 & 43,5 & Özel Sek, Çalışanı & 91 & 21,4 \\
\hline Bekâr & 240 & 56,5 & Serbest Çalışan & 20 & 4,7 \\
\hline \multicolumn{3}{|l|}{ Ĕgitim Durumu } & Emekli & 26 & 6,1 \\
\hline İlköğretim-Ortaokul & 24 & 5,6 & İşsiz & 16 & 3,8 \\
\hline Lise & 52 & 12,2 & \multicolumn{3}{|l|}{ Aylık Gelir } \\
\hline Ön Lisans-Lisans & 272 & 64,0 & $0-2000 £$ & 187 & 44,0 \\
\hline Lisansüstü & 77 & 18,1 & 2001-3000€ & 67 & 15,8 \\
\hline \multicolumn{3}{|l|}{ Yaş } & 3001-5000€ & 98 & 23,1 \\
\hline 15-20 Yaş & 69 & 16,2 & $5001-7000 €$ & 36 & 8,5 \\
\hline 21-35 Yaş & 224 & 52,7 & 7001 モ ve Üzeri & 37 & 8,7 \\
\hline 36-50 Yaş & 90 & 21,2 & & & \\
\hline 51 Yaş ve Üzeri & 42 & 9,9 & & & \\
\hline
\end{tabular}

Tablo 1'e göre, 425 katılımcının 239'u (\%56.2) kadın, 186's1 (\%43.8) erkek iken, 185'i (\%43.5) evli, 240'1 (\%56.5) bekârdır. Yaş gruplarına bakıldığında; katılımcıların büyük çoğunluğunun genç ve orta yaş gruplarından oluştuğu, eğitim durumuna bakıldığında ise büyük çoğunluğun ön lisans- lisans eğitim düzeyinde olduğu görülmektedir. Bununla birlikte öğrencilerin en yüksek katılım oranına sahip olduğu, ögrencilerden sonra kamu sektörü ve özel sektör çalışanlarının diğer gruplara göre daha yüksek katılım gösterdiği gözlenmektedir. Son olarak aylık gelir açısından bakıldığında, 
katılımcıların yaklaşık yarısının 0-2000 € arasında gelire sahip olduğu, diğer katılımcilar arasında ise en fazla gelir aralığının 3001-5000 ‡ olduğu görülmektedir.

\section{Kullanılan Ölçekler ve Analiz Yöntemi}

Veri toplama aracı olarak; araştırmacıların hazırladı̆̆ 1 "Kişisel Bilgi Formu" ile Lee (2020)'nin geliştirdiği ve Biçer ve diğerlerinin (2020) Türkçe 'ye çevirdiği "Koronavirüs Anksiyetesi Ölçeği (KAÖ)" ve Smith ve diğerlerinin (2008) geliştirdiği ve Doğan (2015)'ın Türkçe 'ye çevirdiği 'Kısa Psikolojik Sağlamlık Ölçeği (KPSÖ)" kullanılmıştır. ${ }^{26-29}$ Nicel analiz yöntemi tercih edilen araştırmanın veri analizinde ise SPSS 22 ve AMOS 24 istatistik paket programlarından yararlanılmıştır. Ölçek geçerlik ve güvenirlikleri için doğrulayıcı faktör analizi ve güvenirlik analizi yapılmıştır. Bununla birlikte, demografik farklılıklar analizi kapsamında, iki grup içeren değişkenler (cinsiyet ve medeni durum) için bağımsız örneklem $t$ testi uygulanmış, ikiden fazla grup içeren değişkenler (yaş, eğitim durumu, yapılan iş ve aylık gelir) için ise tek yönlü varyans analizi (ANOVA) ve Post-hoc testi Tukey, LSD ve Games-Howell yöntemleri ile farklılıklar tespit edilmiştir. Daha sonra değişkenler arası ilişki tespiti için korelasyon analizi uygulanmış, koronavirüs anksiyetesinin psikolojik sağlamlık üzerindeki etkisini tespit etmek için ise yapısal eşitlik model analizi uygulanmıştır.

\section{Ölçek Geçerlikleri ve Güvenirlikleri}

Ölçek geçerliği için yapılan doğrulayıcı faktör analizinde koronavirüs anksiyete ölçeğinin 1. maddesi, psikolojik sağlamlık ölçeğinin ise 5. maddesi çok fazla modifikasyon oluşturarak ölçek geçerliklerini düşürdükleri için ölçeklerden çıkarılmıştır. Analizler sonucu elde edilen geçerlik ve güvenirlik değerleri Tablo 2'deki gibidir.

Tablo 2. Ölçeklerin Geçerlik ve Güvenirlik Sonuçları

\begin{tabular}{llllllll}
\hline Değişkenler & $\begin{array}{l}\chi^{2} / \mathbf{d f} \\
\mathbf{\leq 5}\end{array}$ & $\begin{array}{l}\text { GFI } \\
\mathbf{2 0 . 8 5}\end{array}$ & $\begin{array}{l}\mathbf{C F I} \\
\mathbf{2 0 . 9 0}\end{array}$ & $\begin{array}{l}\text { RMSEA } \\
\mathbf{\leq 0 . 0 8}\end{array}$ & $\begin{array}{l}\text { Boyut } \\
\text { Sayısı }\end{array}$ & $\begin{array}{l}\text { Madde } \\
\text { Sayısı }\end{array}$ & $\begin{array}{l}\text { Cronbachs' } \\
\text { Alpha }\end{array}$ \\
\hline $\begin{array}{l}\text { Koronavirüs } \\
\text { Ansksiyete Ölçeği }\end{array}$ & 1.285 & 0.997 & 0.999 & 0.026 & Tek boyut & $\begin{array}{l}4 \\
\text { madde }\end{array}$ & 0.873 \\
$\begin{array}{l}\text { Psikolojik } \\
\text { Sağlamlık Ölçeği }\end{array}$ & 2.380 & 0.991 & 0.992 & 0.057 & Tek boyut & $\begin{array}{l}5 \\
\text { madde }\end{array}$ & 0.813 \\
\hline
\end{tabular}

Tablo 2 incelendiğinde, yapılan geçerlik analizi sonuçlarının her iki ölçek için de iyi uyum değerlerine sahip olduğu, uygulanan güvenirlik analizine göre ise, kullanılan ölçeklerin yüksek güvenirlik düzeyine sahip olduğu tespit edilmiştir.

\section{Araştırmanın Etik Yönü}

Araştırma için Gümüşhane Üniversitesi Bilimsel Araştırma ve Yayın Etiği Kurulu'nun 24/09/2020 tarih ve 2020/9 karar sayısı ile izin alınmıştır. Ayrıca bu araştırma için Sağlık Bakanlığı'ndan 20/12/2020 tarihinde gerekli izin alınmıştır.

\section{BULGULAR VE TARTIŞMA}

Bu bölümde, oluşturulan araştırma modeli ve hipotezler kapsamında, bireylerin koronavirüs anksiyete düzeyleri ve psikolojik sağlamlık düzeylerinin demografik değişkenlere göre farklılık analizi sonuçları ile bağımsız değişken ve bağımlı değişken arasındaki ilişki ve etki analizi sonuçlarına yer verilmektedir.

\section{Demografik Değişkenlere Göre Farklılıkların İncelenmesi}

Katılımciların koronavirüs anksiyete ve psikolojik sağlamlık düzeylerinin cinsiyete, 
medeni duruma, eğitim durumu ve aylık görülmektedir.

gelire göre farklılıkları Tablo 3'de

Tablo 3. Cinsiyete, Medeni Durum, Eğitim Durumu ve Aylık Gelire Göre Farklılıklar

\begin{tabular}{|c|c|c|c|c|c|c|}
\hline Cinsiyet & Gruplar & Sayı & Ortalama & $\begin{array}{l}\text { Standart } \\
\text { Sapma }\end{array}$ & $\mathbf{T}$ & $\mathbf{p}$ \\
\hline Koronavirüs & Kadın & 239 & 2.06 & 0.86 & \multirow{2}{*}{3.181} & \multirow{2}{*}{$0.002 *$} \\
\hline Anksiyetesi & Erkek & 186 & 1.79 & 0.88 & & \\
\hline Psikolojik & Kadın & 239 & 3.18 & 0.88 & \multirow{2}{*}{-3.771} & \multirow{2}{*}{$0.000 *$} \\
\hline Sağlamlık & Erkek & 186 & 3.48 & 0.72 & & \\
\hline $\begin{array}{l}\text { Medeni } \\
\text { Durum }\end{array}$ & Gruplar & Sayı & Ortalama & $\begin{array}{l}\text { Standart } \\
\text { Sapma }\end{array}$ & $\mathbf{F}$ & $\mathbf{P}$ \\
\hline Koronavirüs & Evli & 185 & 2.01 & 0.85 & \multirow{2}{*}{1.365} & \multirow{2}{*}{0.173} \\
\hline Anksiyetesi & Bekâr & 240 & 1.89 & 0.89 & & \\
\hline Psikolojik & Evli & 185 & 3.42 & 073 & \multirow{2}{*}{2.493} & \multirow{2}{*}{ 0.013* } \\
\hline Sağlamlık & Bekâr & 240 & 3.23 & 0.89 & & \\
\hline $\begin{array}{l}\text { Eğitim } \\
\text { Durumu }\end{array}$ & Gruplar & Sayı & Ortalama & $\begin{array}{l}\text { Standart } \\
\text { Sapma }\end{array}$ & $\mathbf{F}$ & $\mathbf{P}$ \\
\hline \multirow{4}{*}{$\begin{array}{l}\text { Koronavirüs } \\
\text { Anksiyetesi }\end{array}$} & $\begin{array}{l}\text { İlköğretim- } \\
\text { Ortaokul }\end{array}$ & 24 & 2.08 & 0.97 & \multirow{4}{*}{1.022} & \multirow{4}{*}{0.383} \\
\hline & Lise & 52 & 2.11 & 0.99 & & \\
\hline & Ön Lisans-Lisans & 272 & 1.91 & 0.86 & & \\
\hline & Lisansüstü & 77 & 1.88 & 0.81 & & \\
\hline \multirow{4}{*}{$\begin{array}{l}\text { Psikolojik } \\
\text { Sağlamlık }\end{array}$} & $\begin{array}{l}\text { İlköğretim- } \\
\text { Ortaokul }\end{array}$ & 24 & 3.38 & 0.72 & \multirow{4}{*}{0.102} & \multirow{4}{*}{0.959} \\
\hline & Lise & 52 & 3.29 & 0.76 & & \\
\hline & Ön Lisans-Lisans & 272 & 3.32 & 0.83 & & \\
\hline & Lisansüstü & 77 & 3.28 & 0.90 & & \\
\hline Aylık Gelir & Gruplar & Sayı & Ortalama & $\begin{array}{l}\text { Standart } \\
\text { Sapma }\end{array}$ & $\mathbf{F}$ & $\mathbf{P}$ \\
\hline \multirow{5}{*}{$\begin{array}{l}\text { Koronavirüs } \\
\text { Anksiyetesi }\end{array}$} & $0-2000 €$ & 187 & 1.86 & 0.85 & \multirow{5}{*}{2.046} & \multirow{5}{*}{0.087} \\
\hline & 2001-3000€ & 67 & 1.92 & 0.83 & & \\
\hline & $3001-5000 €$ & 98 & 2.16 & 0.94 & & \\
\hline & $5001-7000 €$ & 36 & 1.88 & 0.94 & & \\
\hline & 7001 € ve Üzeri & 37 & 1.88 & 0.82 & & \\
\hline \multirow{5}{*}{$\begin{array}{l}\text { Psikolojik } \\
\text { Sağlamlık }\end{array}$} & $0-2000 €$ & 187 & 3.25 & 0.86 & \multirow{5}{*}{0.679} & \multirow{5}{*}{0.607} \\
\hline & 2001-3000€ & 67 & 3.38 & 0.86 & & \\
\hline & 3001-5000€ & 98 & 3.29 & 0.71 & & \\
\hline & 5001-7000 € & 36 & 3.39 & 0.91 & & \\
\hline & 7001 € ve Üzeri & 37 & 3.45 & 0.78 & & \\
\hline
\end{tabular}

Tablo 3'e göre, uygulanan bağımsız örneklem t testi sonucunda, kadın ve erkekler arasında koronavirüs anksiyete düzeyleri ve psikolojik sağlamlık düzeyleri açısından istatistiksel olarak anlamlı farklılık bulunmaktadır. Buna göre kadınların koronavirüs anksiyete düzeyleri erkeklerden anlamlı derecede daha yüksek iken erkeklerin ise psikolojik sağlamlı düzeyleri kadınlardan anlamlı derecede daha yüksektir. Konuyla ilgili yapılan benzer çalışmalarda da kadınların erkeklere göre daha yüksek bir depresyon ve anksiyete semptomları gösterdiği bulunmuştur. ${ }^{30,31,20}$ Artan ve diğerlerinin yaptı̆̆ı çalışmada da kadınların anksiyete düzeyi daha yüksek, psikolojik sağlamlık düzeyi ise daha düşük bulunmuştur. ${ }^{32}$ COVID-19 salgın döneminde Yazıcı Çelebi'nin yaptı̆̆ erkeklerin psikolojik sağlamlık düzeylerinin kadınlardan daha yüksek olduğunu sonucuna ulaşılmıştır. $\mathrm{Bu}$ durum, kadınların daha duygusal bir yapida olmasi ${ }^{33}$ ve ataerkil yapıya sahip toplumlarda erkeklerin daha korumacı ve güçlü yaklaşımlarının bir sonucu olarak daha çabuk toparlanma eğilimi içerisinde olması ile açıklanabilir. Ancak literatürde bu çalışma sonucundan farklı olarak Demir ve Çifçi'nin salgın sürecinde sokağa çıkma kısıtlaması bulunan lise 
öğrencilerinin psikolojik sağlamlık düzeylerini tespit etmek üzere yaptıkları çalışmada kadın katılımcıların psikolojik sağlamlık puanlarının erkeklerden daha yüksek olduğu ortaya konmuştur. ${ }^{34}$ Ayn 1 çalışmada bu bulgunun kız çocuklarının, ani ve istenmeyen risk faktörleri ortaya çıkması durumunda psikolojik ve davranışsal olarak daha yüksek düzeyde uyum gösterme becerilerine sahip olmalarından kaynaklanabileceği belirtilmiştir. Cinsiyet değişkeni açısından literatürde farklı sonuçların olması, yürütülen çalışmaların farklı örneklem gruplarında yapılmasıyla açıklanabilir. Doğrulanan modelin diğer bulgusuna göre, evli ve bekârlar arasında, koronavirüs anksiyete düzeyleri açısından istatistiksel olarak anlamlı farklılık bulunmazken, evlilerin psikolojik sağlamlık düzeyleri bekârlardan anlamlı derecede daha yüksek bulunmuştur. $\mathrm{Bu}$ çalışmadan elde edilen medeni durum ve psikolojik sağlamlıkla arasındaki ilişki Yazıcı Çelebi'nin çalışmasıyla da örtüşmektedir. Buna göre, semptomlar açısından kendini kontrol etme davranışı evlilerde bekarlara göre daha fazladır. ${ }^{33} \mathrm{Bu}$ durum evlilerin eş ve çocukları için daha fazla endişe duyması ve bu konuda sorumluluk almasindan kaynaklanabilir. $\mathrm{Bu}$ çalışmanın bulgularıyla koronavirüs anksiyete düzeyi açısından benzer sonuçların elde edildiği Artan ve diğerleri tarafından yapılan çalışmada evli ya da bekar olma durumunun katilımciların kaygı ve psikolojik sağlamlık düzeylerini etkilemediği görülmüştür. ${ }^{32}$

Çalışma sonucunda elde edilen bir diğer sonuca göre, eğitim durumuna göre koronavirüs anksiyete düzeyleri ve psikolojik sağlamlık düzeyleri açısından istatistiksel olarak anlamlı farklılık bulunmamaktadır. $\mathrm{Bu}$ çalışmanın sonucuna benzer olarak salgın döneminde Karal ve Gül Biçer tarafından yapılan çalışmada da bireylerin psikolojik sağlamlık düzeyi ile eğitim durumu değişkeni arasında istatistiksel olarak anlamlı bir sonuç bulunmamıştır. ${ }^{35}$

Diğer taraftan katılımcıların aylık gelirlerine göre koronavirüs anksiyete düzeyleri ve psikolojik sağlamlık düzeyleri açısından istatistiksel olarak anlamlı farklılık bulunmamaktadır. Artan ve diğerleri tarafından yapılan çalışmada salgın sebebiyle ekonomik endişeleri olan grubun anksiyete düzeylerinin daha yüksek olduğu, psikolojik sağlamlık açısından ise herhangi bir fark olmadığı görülmüştür. ${ }^{32}$

Tablo 4. Yaş Gruplarına Göre Farklılıklar

\begin{tabular}{|c|c|c|c|c|c|c|c|}
\hline Değişkenler & Gruplar & Sayı & Ortalama & Standart Sapma & $\mathbf{F}$ & $\mathbf{p}$ & Fark (Tukey) \\
\hline \multirow{4}{*}{$\begin{array}{l}\text { Koronavirüs } \\
\text { Anksiyetesi }\end{array}$} & 15-20 Yaş & 69 & 1.70 & 0.87 & \multirow{4}{*}{3.377} & \multirow{4}{*}{ 0.018* } & \multirow{4}{*}{ 4-1 } \\
\hline & 21-35 Yaş & 224 & 1.96 & 0.85 & & & \\
\hline & 36-50 Yaș & 90 & 1.95 & 0.90 & & & \\
\hline & 51 Yaş ve Üzeri & 42 & 2.23 & 0.90 & & & \\
\hline & $15-20$ yaş & 69 & 3.24 & 0.91 & \multirow{4}{*}{1.392} & \multirow{4}{*}{0.245} & \multirow{4}{*}{ - } \\
\hline Psikolojik & $21-35$ Yaş & 224 & 3.26 & 0.84 & & & \\
\hline \multirow[t]{2}{*}{ Sağlamlık } & $36-50$ Yaş & 90 & 3.44 & 0.78 & & & \\
\hline & 51 Yaş ve Üzeri & 42 & 3.42 & 0.63 & & & \\
\hline Değişkenler & Gruplar & Sayı & Ortalama & Standart Sapma & $\mathbf{F}$ & $\mathbf{P}$ & Fark (LSD) \\
\hline \multirow{7}{*}{$\begin{array}{l}\text { Koronavirüs } \\
\text { Anksiyetesi }\end{array}$} & Öğrenci & 139 & 1.87 & 0.90 & \multirow{7}{*}{2.405} & \multirow{7}{*}{$0.027 *$} & \multirow{7}{*}{$\begin{array}{l}2-5,7 \\
6-1,3,5,7\end{array}$} \\
\hline & Ev Hanımı & 37 & 2.16 & 0.90 & & & \\
\hline & Kamu Çalışanı & 96 & 1.94 & 0.83 & & & \\
\hline & Özel Sek. Çalışanı & 91 & 1.99 & 0.88 & & & \\
\hline & Serbest Çalışan & 20 & 1.67 & 0.82 & & & \\
\hline & Emekli & 26 & 2.35 & 0.96 & & & \\
\hline & İşsiz & 16 & 1.56 & 0.56 & & & \\
\hline \multirow{7}{*}{$\begin{array}{l}\text { Psikolojik } \\
\text { Sağlamlık }\end{array}$} & Öğrenci & 139 & 3.15 & 0.91 & \multirow{7}{*}{2.904} & \multirow{7}{*}{$0.009 *$} & \multirow{7}{*}{$\begin{array}{l}\text { Fark (Games- } \\
\text { Howell) } \\
\text { 4-1 }\end{array}$} \\
\hline & Ev Hanımı & 37 & 3.31 & 0.80 & & & \\
\hline & Kamu Çalışanı & 96 & 3.29 & 0.83 & & & \\
\hline & Özel Sek. Çalışanı & 91 & 3.60 & 0.70 & & & \\
\hline & Serbest Çalışan & 20 & 3.14 & 0.67 & & & \\
\hline & Emekli & 26 & 3.40 & 0.69 & & & \\
\hline & İşsiz & 16 & 3.25 & 0.82 & & & \\
\hline
\end{tabular}


Tablo 4'e göre, uygulanan tek yönlü varyans analizi (ANOVA) sonucunda katılımcıların yaş gruplarına göre koronavirüs anksiyete düzeyleri açısından istatistiksel olarak anlamlı farklılık bulunmaktayken, psikolojik sağlamlık düzeyleri açısından istatistiksel olarak anlamlı farklılık bulunmamaktadır. Buna göre, 51 yaş ve üzeri yaş grubunda bulunan katılımcıların yani ileri yaş bireylerin koronavirüs anksiyete düzeyleri 15-20 yaş grubunda olan katılımcılardan yani genç ve çocuklardan anlamlı derecede daha yüksektir. Yapılan çalışmalarda bu sonuçtan farklı bulgular elde edilmiştir. Çalışmalarda yaş açısından gençlerin daha fazla kaygı yaşadığı bildirilmiştir. ${ }^{36,37}$ Literatürden farklı sonuçlar elde edilmesinin nedeni araştırma zamanlarındaki farklılıklar olabilir. $\mathrm{Bu}$ çalışmanın yürütüldügü dönemde ülkemizde 15-20 yaş arası bireyler için herhangi bir kisitlamanın bulunmaması bir rehavet ortamı yaratmış olabilir. Son olarak katılımcıların yapılan işe göre koronavirüs anksiyete düzeylerinin ve psikolojik sağlamlık düzeylerinin farklılaştı̆ğ görülmüştür. Buna göre, ev hanımlarının koronavirüs anksiyete düzeylerinin serbest çalışanlar ve işsizlerden anlamlı derecede daha yüksek, emeklilerin koronavirüs anksiyete düzeylerinin ise öğrenciler, kamu çalışanları, serbest çalışanlar ve işsizlerden anlamlı derecede daha yüksek olduğu tespit edilmiştir. Bununla birlikte, özel sektör çalışanlarının psikolojik sağlamlık düzeyleri öğrencilerden anlamlı derecede daha yüksektir. Diğer taraftan araştırma kapsamında yapılan iş türüne göre koronavirüs anksiyetesi yüksekliği sırasıyla emekli, ev hanımı, özel sektör çalışanı, kamu çalışanı, öğrenci ve işsiz şeklindedir. Bu grup içerisinde en yüksek psikolojik sağlamlık düzeyi ise özel sektör çalışanlarındadır. $\mathrm{Bu}$ süreçte gerçekleştirilen bir başka çalışmada; pandemik kaygının psikolojik iyi oluş üzerindeki olumsuz etkisi kamuda yok denecek kadar az iken özel sektörde bu etkinin çok daha yüksek olduğu ve pandemik kaygının özel sektör çalışanlarını daha fazla sarstığ1 tespit edilmiştir. ${ }^{38}$ Buradan hareketle çalışan grup içerisinde kamuya göre özel sektör çalışanlarının bu salgından daha fazla etkilendiği söylenebilir.

\section{Değişkenler Arasındaki İlişkiye Yönelik Korelasyon Analizi Sonuçları}

Bağımsız değişken olan koronavirüs anksiyetesi ile bağımlı değişken olan psikolojik sağlamlık arasındaki ilişkiyi tespit etmek amaciyla yapilan korelasyon analizi sonuçları Tablo 5'de görülmektedir.

Tablo 5. Değişkenler Arasındaki İlişki Düzeyi ve Yönü

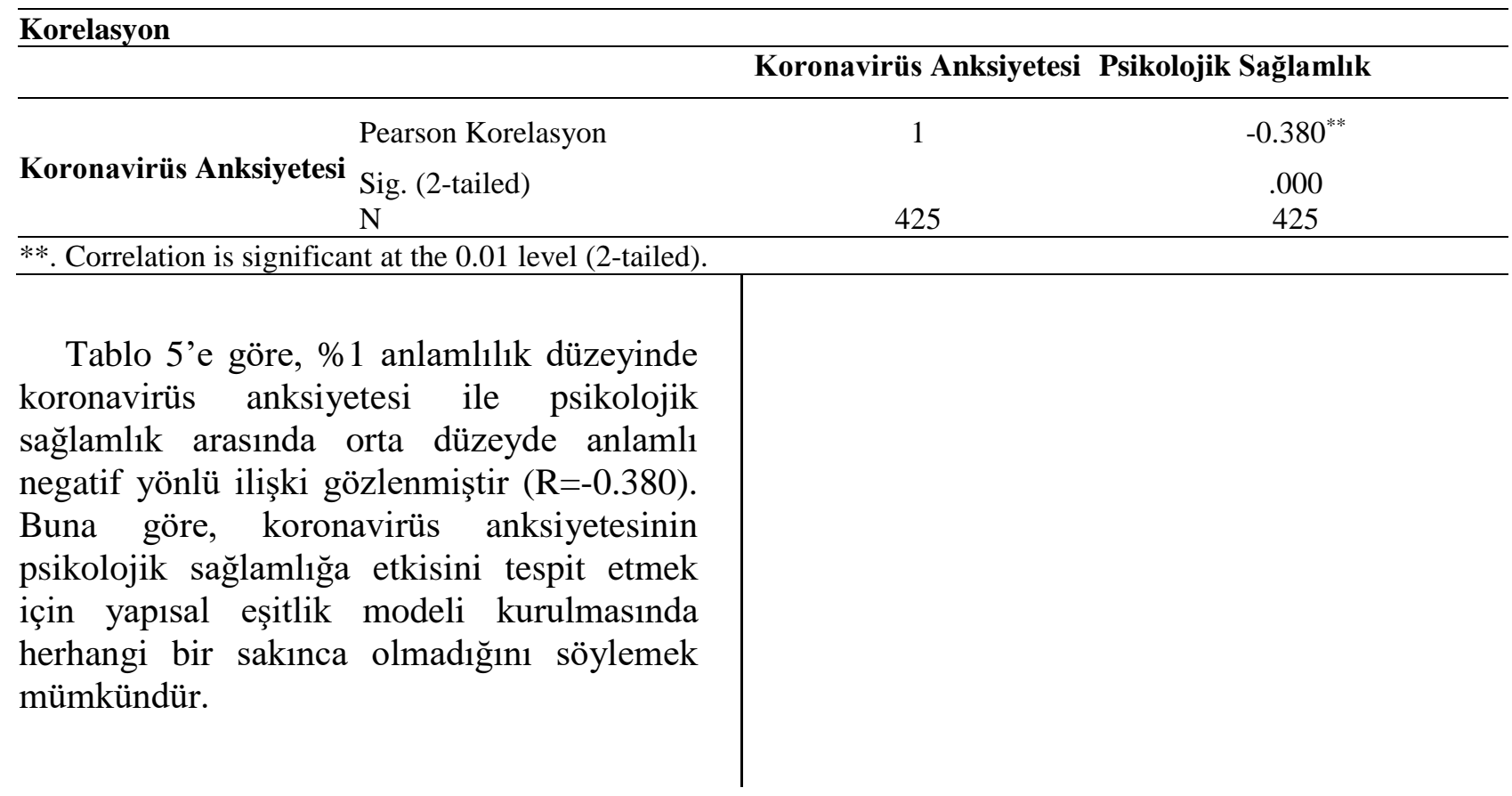




\section{Yapısal Eşitlik Modeliyle Etki Analizi} Sonuçları

Koronavirüs anksiyetesinin psikolojik sağlamlık üzerindeki etkisini gösteren yapısal eşitlik model analizine göre elde edilen bulgular kapsaminda, koronavirüs anksiyetesinin psikolojik sağlamlık üzerinde istatistiksel açıdan anlamlı ve negatif yönde orta düzeyde etkisinin olduğu, psikolojik sağlamlıkta meydana gelebilecek bir azalmanın \%20'sinin koronavirüs anksiyetesi ile açıklanabileceği tespit edilmiştir (Standardize $\beta=-0.439, \mathrm{R}^{2}=0.193, \mathrm{p} \leq 0.05$ ). Buradan hareketle, araştırma modeli ve hipotezleri test etmek için kurulan yapısal eşitlik modelinin doğrulandığını ifade etmek mümkündür.

\section{SONUÇ VE ÖNERILER}

$\mathrm{Bu}$ çalışma, koronavirüs anksiyetesinin psikolojik sağlamlık üzerinde istatistiksel açıdan anlamlı ve negatif yönde orta düzeyde etkisinin olduğunu, psikolojik sağlamlıkta meydana gelebilecek bir azalmanın \%20'sinin koronavirüs anksiyetesi ile açıklanabileceğini göstermiştir. Daha açık bir ifadeyle kişinin koronavirüs salgını döneminde yaşadığı anksiyete (kaygı) psikolojik sağlamlığını etkilemektedir. Elde edilen bu sonuç alan yazınla da örtüşmektedir. Buna göre; psikolojik sağlamlık düzeyleri yüksek olan bireyler, yaşamları açısından beklenmedik bir durum karşısında daha az anksiyete belirtisi göstermekte ve durum karşısında daha sakin kalabilmektedir. $^{25,39}$ COVID-19 salgın sürecinde Artan ve diğerlerinin yaptıkları çalışmada da psikolojik sağlamlık arttıkça anksiyete düzeylerinin azaldığı ve katılımcıların psikolojik sağlamlık düzeyi arttıkça önleyici davranışlarda bulunma düzeyinin arttığ1 görülmüştür. ${ }^{32}$

Yine bu süreçte Kasapoğlu'nun gerçekleştirdiği çalışmada psikolojik sağlamlık düzeyi yüksek olan bireylerin belirsizliğe tahammül düzeyinin arttığ 1 , kaygı düzeylerinin ise azaldığ ulaşılmıştır. ${ }^{40}$ Gerek bu çalışmada gerekse diğer çalışmalarda elde edilen bu bulgu salgının seyri açısından oldukça önemlidir.

Sonuç olarak; COVID-19 salgını tüm dünyada olduğu gibi ülkemizde de bireyleri fiziksel ve psikolojik olarak etkileyen ve etkilemeye devam eden bir sürecin yaşanmasına neden olmaktadır. Salgının olumsuz etkileriyle başa çıkmada bireylerin psikolojik sağlamlık düzeyleri oldukça önemlidir. $\mathrm{Bu}$ açıdan sürece katk1 sağlayacağ 1 düşünülerek gerçekleştirilen bu çalışmada koronavirüs anksiyetesi ile psikolojik sağlamlık arasındaki ilişki incelenmiştir. Buna göre koronavirüs anksiyetesi ile psikolojik sağlamlık arasında istatistiksel açıdan anlamlı ve negatif yönde orta düzeyde bir ilişki tespit edilmiştir. Ayrica bu etkide cinsiyet, medeni durum, yaş, yapılan iş türü gibi bazı demografik değişkenlerin etkisi olduğu bulunmuştur. Elde edilen sonuçlar ve ilgili literatür 1şığında özel sektör çalışanları başta olmak üzere sirasıyla kadın, emekli, ev hanımı ve yaşlı gibi hassas gruplardan başlanmak üzere bireylerde kaygıyı azaltıcı psikolojik sağlamlığı arttırıcı çalışmaların yapılması önerilmektedir. Salgının neden olduğu anksiyete semptomlarının azaltılması ve psikolojik sağlamlığın artırılması için salgınla ilgili uzun süre haber izlenmemesi, düzenli egzersiz yapılması, sağlıklı beslenilmesi ve COVID-19 ile ilgili bilgi alma konusunda yalnızca bu konuda eğitim almış sağlık uzmanlarından tıbbi tavsiye alınması önerilmektedir. Ayrıca izolasyon ve karantina dönemlerinde telefon görüşmeleri veya video görüşmeleri yoluyla arkadaş veya aile ile iletişim halinde olmak, bu sürecin daha iyi yönetilmesine katkı sağlayabilir. Son olarak olabildiğince pozitif düşünmenin ve salgın tehdidini kabul edip gerekli önlemleri almanın bu sürecin sağlıklı atlatılabilmesine katkı sağlayacağı belirtilmelidir. 


\section{KAYNAKLAR}

1. World Health Organization (WHO). (2020), March 11. WHO Director-General's Opening Remarks at the MediaBbriefing on COVID-19. Retrieved March 11. from https://www.who.int/dg/speeches/detail/who-director-general-sopening-remarks-at-themedia-briefing-on-covid-19.

2. Shanafelt, T, Ripp, J. and Trockel, M. (2020). "Understanding and Addressing Sources of Anxiety among Health Care Professionals during the COVID-19 Pandemic". Journal of American Medical Association, 323 (21), 2133-2134.

3. Lee, S.A, Mathis, A.A, Jobe, M.C. and Pappalardo, E.A (2020). "Clinically Significant Fear and Anxiety of COVID-19. A Psychometric Examination of the Coronavirus Anxiety Scale". Psychiatry Research, 20, 290, 1-7.

4. Stankovska, G, Memedi, I. and Dimitrovski, D. (2020). "Coronavirus COVID-19 Disease, Mental Health and Psychosocial Support”. Society Register, 4 (2), 33-48.

5. Wang, C, Pan, R, Wan, X, Tan, Y, Xu, L, Ho, C.S. and Ho, R.C. (2020). "Immediate Psychological Responses and Associated Factors during The Initial Stage of The 2019 Coronavirus Disease (COVID-19) Epidemic among The General Population in China". International Journal of Environmental Research and Public Health, 17 (5), 1729.

6. Cao, W, Fang, Z, Hou, G, Han, M, Xu, X, Dong, J. and Zheng, J. (2020). "The Psychological Impact of The COVID-19 Epidemic on College Students in China". Psychiatry Research, 287, doi: 10.1016/j.psychres.2020.112934.

7. Huang, Y. and Zhao, N. (2020). Generalized Anxiety Disorder, Depressive Symptoms and Sleep Quality during COVID-19 Outbreak in China: A Web-Based Cross-Sectional Survey. Psychiatry Research, 288, doi:10.1016/j.psychres.2020.112954.

8. Wang, C, Pan, R, Wan, X, Tan, Y, Xu, L, Ho, C.S. and Ho, R.C. (2020). "Immediate Psychological Responses and Associated Factors during The Initial Stage of The 2019 Coronavirus Disease (COVID-19) Epidemic among The General Population in China". International Journal of Environmental Research and Public Health, 17 (5), 1729.

9. Qiu, J, Shen, B, Zhao, M, Wang, Z, Xie, B. and Xu, Y. (2020). "A Nationwide Survey of Psychological Distress among Chinese People in The COVID-19 Epidemic: Implications and Policy Recommendations”. General Psychiatry, 33, 100213.

10. Li, W, Yang, Y, Liu, Z. H, Zhao, Y. J, Zhang, Q, Zhang, L, Cheung, T. and Xiang, Y.T. (2020). "Progression of Mental Health Services during The COVID-19 Outbreak in China". International Journal of Biological Sciences, 16 (10), 17321738 .

11. Jalloh, M.F, Li, W, Bunnell, R.E, Ethier, K.A, O'Leary, A Hageman, K.M. and Redd, J.T. (2018). "Impact of Ebola Experiences and Risk Perceptions on Mental Health in Sierra Leone". BMJ Global Health. 3 (2), doi: 10.1136/bmjgh-2017000471 .

12. Lau, J.T.F, Griffiths, S, Choi, K.C. and Tsui, H.Y. (2010) "Avoidance Behaviors and Negative Psychological Responses in The General Population in The Initial Stage of The H1N1 pandemic in Hong Kong”. BMC Infectious Diseases. 10 (139), doi: 10.1186/1471-2334-10-139.

13. Main, A, Zhou, Q, Ma, Y, Luecken, L.J. and Liu, X. (2011) "Relations of SARS-Related Stressors and Coping To Chinese College Students' Psychological Adjustment during the 2003 Beijing SARS Epidemic". Journal of Counseling Psychology. 58 (3), 410-423.
14. Erdoğan, A. ve Hocaoğlu, Ç. (2020). Enfeksiyon Hastalıklarının Ve Pandeminin Psikiyatrik Yönü: Bir Gözden Geçirme. Klinik Psikiyatri Dergisi, 23(1), 72-80.

15. Arden, M.A. and Chilcot, J. (2020). "Health Psychology and The Coronavirus (COVID-19) Global Pandemic: A Call For Research". British Journal of Health Psychology, Editorial. DOI:10.1111/ bjhp.12414.

16. Köknel, Ö. (1989). Kaygı Bozuklukları Genel ve Klinik Psikiyatri. İstanbul: Nobel Tıp Yayını.

17. Spielberger, C.D. (1971). Theory and Research on Anxiety. Anxiety and Behavior (third ed.). New York: Spielberger Academic Press Inc,

18. Rachel, B. and Chidsey. A. (2005). Assessment for Intervention: A Problem Solving Approach. The Guilford Press, pp.26-32.

19. Kluge, H.H.P. (2020). Statement-Physical and mental health key to resilience during COVID-19 pandemic. 26 March 2020, Copenhagen, Denmark. http://www.euro.who.int/en/media centre/sections/statements/2020/statement-physical-and-mentalhealth-key-to-resilienceduring-covid-19-pandemic.

20. Tönbül, Ö. (2020). “Koronavirüs (Covid-19) Salgını Sonrası 20-60 Yas Arası Bireylerin Psikolojik Dayanıklılıklarının Baz Değişkenler Açısından İncelenmesi”. Uluslararası Akademik Psikolojik Danışma ve Rehberlik Araştırmaları Dergisi, 2 (2), 159-174.

21. Hunter, A.J. and Chandler, G.E. (1999). "Adolescent Resilience. Image”. Journal of Nursing Scholarship, 31 (3), 243-247.

22. Hoşoğlu, R, Fırıncı Kodaz, A, Yılmaz Bingöl, T. ve Vural Batık, M. (2018). "Öğretmen Adaylarında Psikolojik Sağlamlık”. Uluslararası Toplum Araştırmaları Dergisi, 14 (8), 219-239.

23. Block, J.H. and Block, J. (1980). The Role of Ego-Control and Ego Resiliency in The Organization Of Behavior W.A. Collins (Ed.), Minnesota Symposium on Child Psychology, Erlbaum, Hillsdale, NJ, 39-101.

24. Luthar, S.S, Cicchetti, D. and Becker, B. (2000). The Construct of Resilience: A Critical Evaluation and Guidelines For Future Work. Child Development, 71(3), 543-562.

25. Fredrickson, B.L, Tugade, M.M, Waugh, C.E. and Larkin, G.R (2003). "What Good Are Positive Emotions in Criese? A Prospective Study of Resilience and Emotions Following The Terrorist Attacks on the United States on September 11th, 2001". Journal of Personality and Social Psychology, 84 (2), 365-376.

26. Lee, S.A. (2020) "Coronavirus Anxiety Scale: A Brief Menta Health Screener for COVID-19 Related Anxiety". Death Studies, 44 (7), 393-401.

27. Biçer, İ, Çakmak, C, Demir, H. ve Kurt, M.E. (2020). "Koronavirüs Anksiyete Ölçeği Kısa Formu: Türkçe Geçerlik Ve Güvenirlik Çalışması”. Anadolu Kliniği Tıp Bilimleri Dergisi, 25 (Ek 1), 216-225

28. Smith, B.W, Dalen, J, Wiggins, K, Tooley, E, Christopher, P. and Jennifer Bernard, J. (2008). The Brief Resilience Scale: Assessing The Ability to Bounce Back. International Journal of Behavioral Medicine, 15, 194-200.

29. Doğan, T. (2015). “Kısa Psikolojik Sağlamlık Ölçeği'nin Türkçe Uyarlaması: Geçerlik Ve Güvenirlik Çalıșması”. The Journal of Happiness \& Well-Being, 3 (1), 93-102. 
30. Mazza, C, Ricci, E, Biondi, S, Colasanti, M, Ferracuti, S Napoli, C. and Roma, P. (2020). "A Nationwide Survey of Psychological Distress among Italian People During The Covid-19 Pandemic: Immediate Psychological Responses and Associated Factors". International Journal of Environmental Research and Public Health, 17 (9), 1-14.

31. Wang, Y, Wang, Y, Chen, Y. and Qin, Q. (2020). "Unique Epidemiological and Clinical Features of The Emerging 2019 Novel Coronavirus Pneumonia (COVID-19) Implicate Special Control Measures". Journal of Medical Virology, 92 (6), 568576.

32. Artan, T, Atak, I, Karaman M. ve Cebeci, F. (2020). "Koronavirüs (COVID-19) Salgınında Sosyodemografik Özellikler, Psikolojik Sağlamlık Ve Kaygı Düzeyleri Arasındaki İlişki”. Turkish Studies, 15 (6), 79-94.

33. Yazıcı Celebi, G. (2020). "Covid 19 Salgınına İlișkin Tepkilerin Psikolojik Sağlamlık Açısından İncelenmesi”. IBAD Sosyal Bilimler Dergisi, (8), 471-483.

34. Demir, A. ve Çifçi, F. (2020). "Covıd-19 pandemi sürecinde egzersizin lise öğrencilerinin psikolojik sağlamlık düzeylerine etkisinin incelenmesi”. Spormetre-The Journal of Physical Education and Sport Sciences, 18 (3), 169-179.

35. Karal, E. ve Gül Biçer, B. (2020). "Salgın Hastalık Döneminde Algılanan Sosyal Desteğin Bireylerin Psikolojik Sağlamlığı Üzerindeki Etkisinin İncelenmesi”. Birey ve Toplum Sosyal Bilimler Dergisi, 10 (1), 129-156.

36. Moghanibashi-Mansourieh, A. (2020). "Assessing the Anxiety Level of Iranian General Population During COVID-19 Outbreak". Asian Journal of Psychiatry, 51, 1-5.

37. Qiu, J, Shen, B, Zhao, M, Wang, Z, Xie, B, Xu, Y. (2020). “A Nationwide Survey of Psychological Distress among Chinese People in the COVID-19 Epidemic: Implications and Policy Recommendations". General Psychiatry, 33, 1-3.

38. Çiçek, B. ve Almalı, V. (2020). "COVID-19 Pandemisi Sürecinde Kaygı Öz-Yeterlilik Ve Psikolojik İyi Oluş Arasındaki İlișki: Özel Sektör Ve Kamu Çalıșanları Karşılaştırması". Turkish Studies, 15 (4), 241-260.

39. Hjemdal, O, Vogel, P.A, Solem, S, Hagen, K, Stiles, T.C (2011). "The Relationship Between Resilience and Levels of Anxiety, Depression, and Obsessive Compulsive Symptoms in Adolescents". Clinical Psychology and Psychotherapy, 18 (4), 314-321.

40. Kasapoğlu, F. (2020). "COVID-19 Salgını Sürecinde Kaygı İle Maneviyat, Psikolojik Sağlamlı Ve Belirsizliğe Tahammülsüzlük Arasındaki İlişkilerin İncelenmesi”. Turkish Studies, 15 (4), 599-614. 